\title{
Parks for people - a case study from the Aïr Mountains of Niger
}

\author{
John E. Newby
}

\begin{abstract}
The Air Mountains of north-central Niger are relatively unspoilt and contain some of the last remaining populations of addax Addax nasomaculatus, ostrich Struthio camelus and dama gazelle Gazella dama in West Africa. The Air Mountains are also home for some 5000 Twaregs, half of whom are cultivators and the other half herders. The Air and Ténéré National Nature Reserve, which was gazetted in 1988, covers more than $77,000 \mathrm{sq} \mathrm{km}$. It was inspired by concern for the region's unique and increasingly threatened wildlife, but its role and objectives take into account the human dimension of the area's ecology. The Nigerien Wildlife Service and the IUCN/WWF project that supports the reserve are attempting to reconcile conservation with development through a broadly based programme geared to protection, restoration and sustainable use of the area's natural resources.
\end{abstract}

\section{Introduction}

The Republic of Niger is a vast, land-locked, Sahelian nation with a population of over 7 million inhabitants. For the majority of these people life ciepends on the country's limited natural resources: soil, surface or shallow water tables, pasture and a variety of forest products, including timber for fuel and construction. Agriculture is predominantly seasonal and herding extensive, with both taking place under a climatic regime that heavily underlines their subsistence nature. Whilst socially and economically the only realistic options available for the time being, these activities are not only prone to the effects of drought, poor land use and desertification, but they also contribute to their propagation.

The Air Mountains are situated in northcentral Niger and cover some $125,000 \mathrm{sq} \mathrm{km}$ of arid terrain, ranging from granitic and volcanic peaks (up to $2000 \mathrm{~m}$ ), through stony plateaux, and into the sandy, desert country of the Sahara (Figure 1). Drainage features are prominent within the landscape, and with their relatively dense vegetation contrast starkly with the largely abiotic surroundings.

The climate of the Air is hot and extremely arid with temperatures ranging from just below freezing in January to around $50^{\circ} \mathrm{C}$ in May and June. The average annual temperature is about $28^{\circ} \mathrm{C}$. Lying as the region does at the northernmost reaches of the Intertropical Convergence Zone, rainfall is both sparse and seasonal in occurrence. Furthermore, its distribution and therefore that of any resultant pasture, is totally unpredictable. Rainfall varies from 0 to $125 \mathrm{~mm}$ annually, depending on the locality and the year (Newby, 1990). As an indication of aridity and water deficit, measured evaporation is in the order of 3000-4000 mm annually. Perhaps more important than rainfall, is the concentrating effect of the drainage patterns on the large volumes of water that run off the rocky slopes and mountain sides after even the briefest of showers. As a consequence, the vegetation of the larger wadis is more typical of areas benefiting from higher rainfall (de Mire and Gillet, 1956).

Because of its location, bridging the Sahara and the Sahel, and mountainous nature, the Air is both topographically and biologically more diverse than the lowland, desert and sub-desert habitats surrounding it. As a result, the Air has consistently attracted the attention of travellers and scientists. The technical notes 
made by Barth during travels in the region in 1850 (Barth, 1857-8) have been supplemented by the writings and collections of a number of authors, including Foureau (1902), Buchanan (1921), Rodd (1926), Chopard and Villiers (1950), Lhote (1961), Fairon (1975), Peyre de Fabregues and Lebrun (1976), and Morel (1985).

Since 1979, the biology of the Air has come under the close scrutiny of both WWF (The World Wide Fund for Nature) and IUCN (The World Conservation Union). Attracted by the area's relatively unspoilt nature, and more specifically by the need to protect some of the last remaining populations of addax Addax nasomaculatus, ostrich Struthio camelus and dama gazelle Gazella dama in West Africa, scientists have added considerably to knowledge on this unique area's fauna and flora (Newby and Jones, 1980; Dulieu, 1981; Grettenberger $e t$ al., 1984; Monson, 1985; Newby and Grettenberger, 1986; J. Watkins, 1986; L. Watkins, 1986; Grettenberger, 1987; Newby et al., 1987; Grettenberger and Newby, 1990a,b; Magin, 1991 a,b,c,d.

To date, some 40 species of mammal, 160 species of bird and 350 species of plant have been identified. Besides regionally rare mammals, like the addax, cheetah Acinonyx jubatus and dama gazelle, the Air harbours small populations of the wild relatives of several crops: olive Olea lapperinei, millet Pennisetum glaucum and sorghum Sorgho aethiopicum (Newby, 1986; Ingram, 1990).

Archaeological research has shown that the Aïr and Ténéré have been occupied for at least 30,000 years (Durand et al., 1983; Roset, 1989). The area is rich in stone-age sites, many of

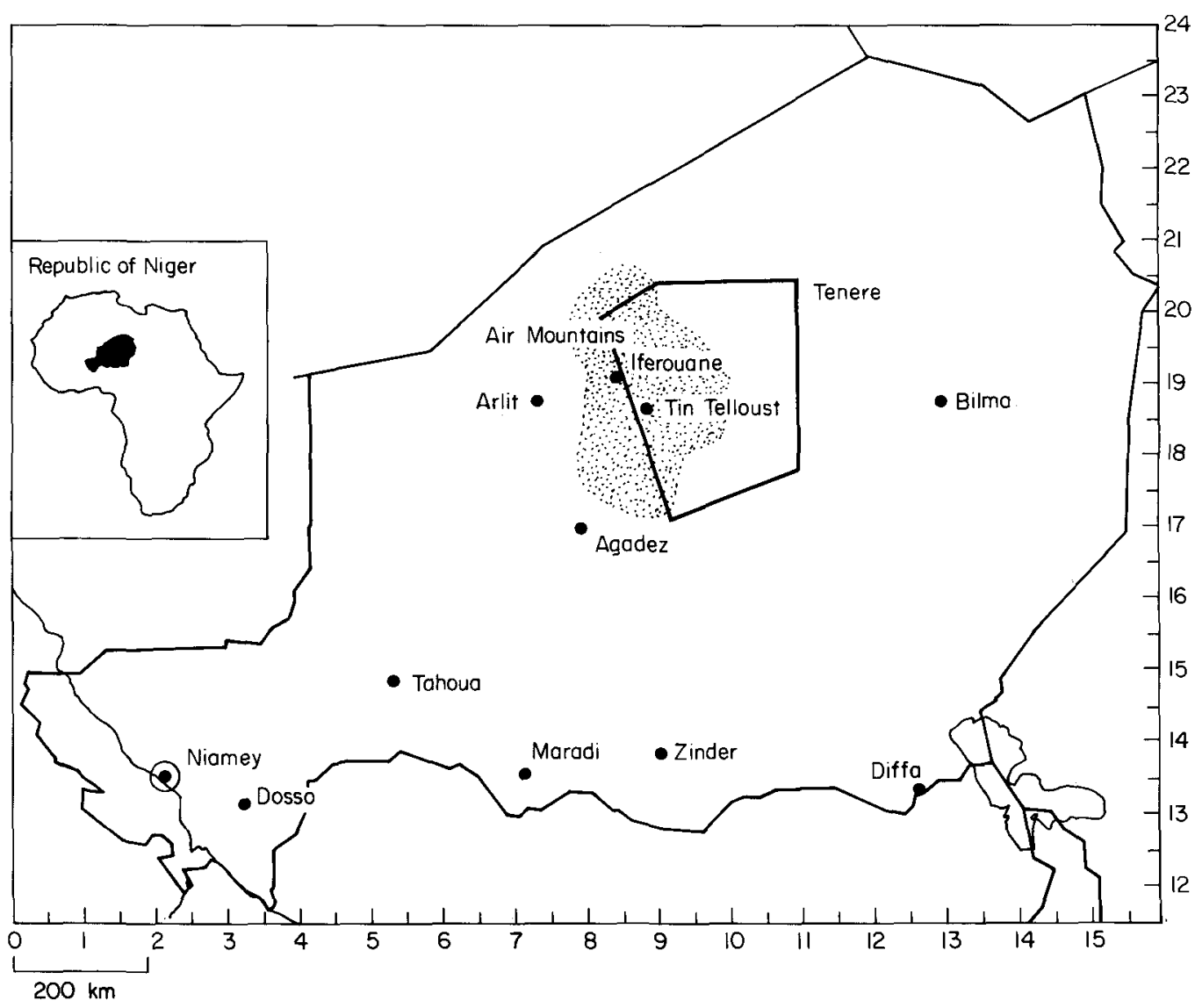

Figure 1. Location of the Aïr Mountains and the Aïr and Ténéré National Nature Reserve. 


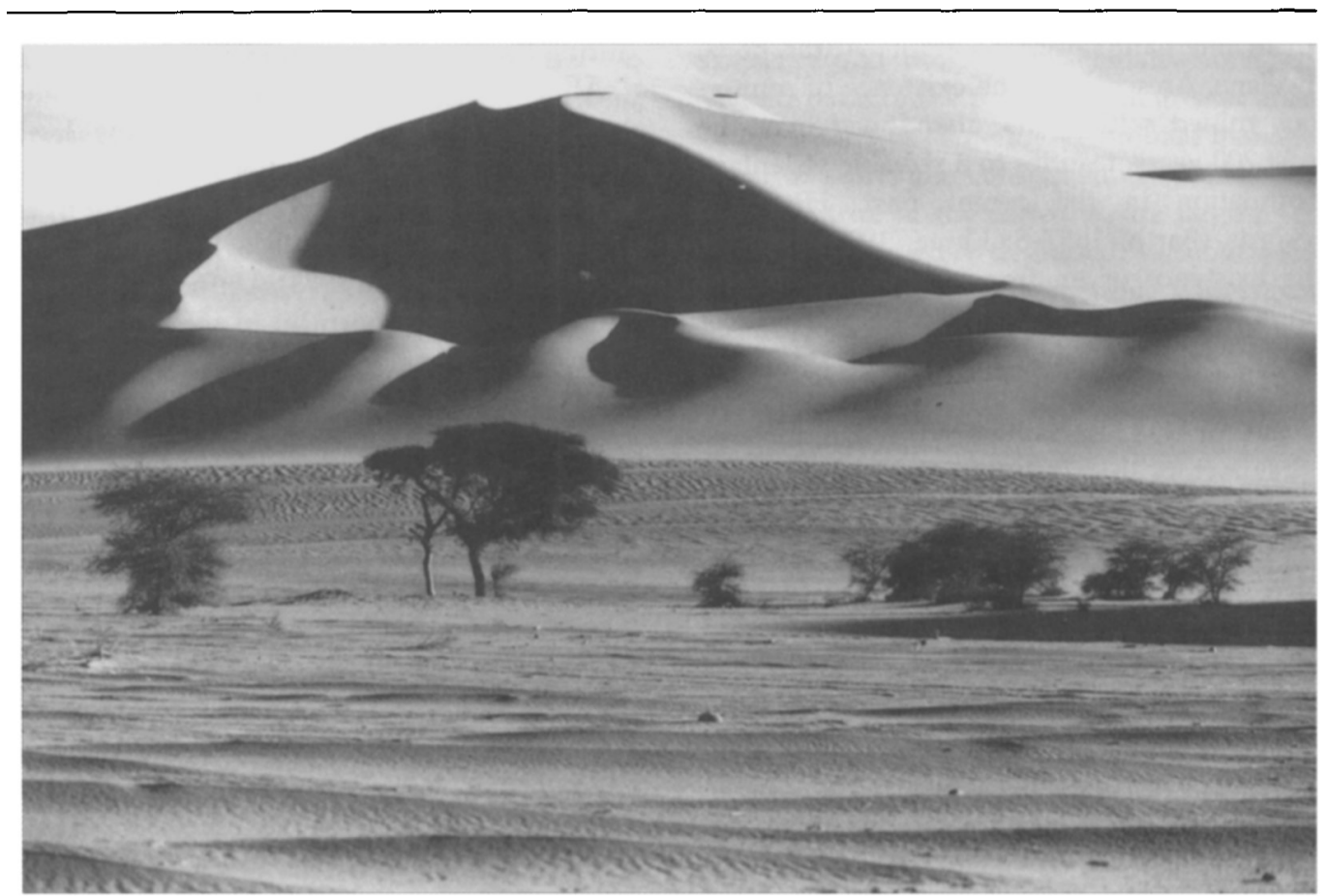

The Aïr and Ténéré Reserve contains some of the most spectacular desert scenery in the Sahara (John Newby/WWF).



Camels and goats are the mainstays of the Aïr's pastoral Twareg (John Newby/WWF). 
them internationally important (Adrar Bous, Iwelene, Areschima). The existence of numerous ruined settlements, abandoned over the past 200 years, testifies to a sizeable sedentary population in the recent past. Historical records (Barth, 1857-8; Lhote, 1976) indicate the existence of an important trans-Saharan trade route through the Aïr Mountains. Whilst undoubtedly suffering the effects of the opening up of coastal trade routes, the population of the Aïr was also influenced by a number of other factors that include colonization, tribal warfare, drought and disease (Fugelstad, 1983). French colonization of the Aïr began in 1898 but it was not until the 1920 s that the region was completely 'pacified'. The period from 1910 to 1920 was particularly disruptive, including not only a severe drought and epidemic of influenza, but also a civil uprising that was severely quashed by the French (Salifou, 1973).

These events appear to have had serious implications for the indigenous systems of conservation and management of the Aïr's pastoral resources. Tribal ownership of the land was irrevocably disrupted by the mass exodus and weakening of formerly powerful groups. With them went the traditional mechanisms and checks that had insured a certain degree of rational land use.

\section{The situation today}

Today, some 5000 Twaregs inhabit the Northern Aïr, half of them living in and around the villages of Iferouane and Tin Telloust (Figure 1). Like their forebears, the sedentary population depends for the most part on the cultivation of small plots of land irrigated by animal traction from shallow wells. A variety of cereals and vegetables is grown, including wheat, maize, tomatoes, peppers and onions (Hammer, 1990). The remainder of the population raises small herds of goats, sheep and camels. Unlike the plainsdwelling nomads of the Sahel, the herders of the Air practice a transhumant form of husbandry, frequenting the wooded valleys during the dry season and lower, fringing plains during the rains (Hagener, 1990).

Although a shadow of its former self, the caravan trade still contributes to the local economy, providing an outlet for garden produce and a means of procuring cereals from the grain-producing regions of Southern Niger (Bernus and Bernus, 1973). Unfortunately, the caravan trade has been hit in recent times by the effects of drought on the pack camels and by competition from motorized transport. Whereas the caravan trade used to function on a mutually acceptable and interdependent system of barter (garden produce and meat for salt and dates; salt and dates for cereals and other necessities), modern commerce has introduced a monetary dimension that favours few but the rich, truck-owning merchants.

Considering the Air's environment and ecology, the land use currently practised would seem not only the most appropriate but also by and large the most sustainable. Whether due to its isolation, the sparsity of its resources or the rigours of its climate, there appears to exist a rude but effective balance between the Airr's relatively small human population and its natural resources. The fact that wildlife and stands of healthy trees can still be seen bears witness to this. During times of plenty, the people are able to satisfy their basic needs without endangering the survival or perenniality of the resources they rely upon. In periods of drought, however, the demand on the limited supplies of water and vegetation increases and if prolonged, leads to crop failure, widespread overgrazing, loss of livestock, mass exodus of the human population and not infrequently, death from disease or starvation. Although the aridland ecosystems of the Air exhibit a high degree of resilience to drought, natural regeneration may take many years, even when left alone. Habitats rarely fully recover from prolonged drought combined with excessive human pressure. Rehabilitation of degraded aridlands is theoretically possible, but it seldom occurs without considerable external assistance (reseeding, afforestation, watershed management), great cost and, even then, only over relatively small areas.

If left 'untouched' by the outside world, the 
Twareg of the Air might well manage to remain in balance with their environment for some time to come. Although the fluctuations in the brutal equilibrium they do maintain may be ecologically 'acceptable', they are not so ethically or politically. In spite of its capacity to cope with the rigours of survival in a marginal environment, the nomadic tradition is hard pressed to keep up with the political and climatic changes that have affected the Twareg and their social fabric during the twentieth century.

In the absence of viable alternatives, the future of the Air Twareg would seem tied to their ability to pursue traditional, natural resource-based occupations whilst exploiting any other appropriate opportunities that arise. The latter already include employment in the nearby mining towns, temporary emigration towards the labour markets of North Africa, and the expanding tourist industry. In short, the survival of the Air Twareg is dependent on him maintaining socio-economic strategy that is as broadly based as possible.

\section{Protected areas and development}

In West Africa at least, it is clear that protected areas are rapidly becoming the only places where a semblance of former ecological and biological diversity persists. Besides their intrinsic cultural and scientific values, these parks and reserves are often critical for the maintenance of life-support systems such as watersheds and fisheries.

Much as parks and reserves are highly important tools for the conservation of nature, the protected areas concept needs to be adapted and applied more widely to the management of the less exotic but equally important utilitarian resources such as land, soil, pasture and water. While change is on its way in the form of Biosphere Reserves, progress is still hampered by the misconception that parks and reserves should be 'no go' areas set aside for wildlife, where the human being is seen more as an inconvenience than as an integral part of the ecosystem. While there will always be a need for traditional parks and reserves to conserve and protect representative or spectacular parts of the planet, much greater areas of land need to come under rational management or suffer the consequences. This is particularly true of the Sahel, where large tracts are already severely degraded. Without some kind of management structure, widespread environmental misuse and degradation can hardly be tackled in a radical enough way to prevent natural resources falling below a point of no recovery, or beyond the threshold at which they can sustain man and his use of them. However, it is important to realize that, although most Sahelians do appreciate the follies of overgrazing, inappropriate agriculture and soaring firewood consumption, there is precious little they can do about it in the absence of socially, politically and economically acceptable alternatives. Providing that there is adequate consultation with local people at all stages, the protected areas approach of identifying conservation or land-use problems in a well-defined area, and then tailoring legislation and management to deal with them, would seem a good way of tackling those problems in accordance with local needs and conditions.

\section{The Airr and Ténéré National Nature Reserve}

When the establishment of a protected area for the Air was first proposed in 1982 (Newby, 1982), the initiative was primarily motivated by concern for the region's unique and increasingly threatened fauna and flora. Wildlife was under pressure from uncontrolled hunting and tourist harassment, and after several years of drought, woody vegetation was being rapidly destroyed by overuse and abusive cutting. By the time a reserve was finally gazetted in January 1988, its role and objectives had evolved considerably to take into full account the human dimension of the area's ecology. With an area of just over 77,000 sq km, the Aïr and Ténéré National Nature Reserve is one of the largest protected areas in the world (about twice the size of Switzerland). It is managed by the Nigerien 
Wildlife Service and boasts a staff of over 40 people, ranging from foresters and wildlife experts to guides, nurserymen and extension agents. Funding of the reserve's conservation and development activities is assured by a consortium of donors, which includes WWF, IUCN, the Swiss and Danish governments, and Band Aid.

Without neglecting the reserve's unique role as a refuge for endangered wildlife, work is being done to address the problems of natural resource use, management and planning. While the people's impact on the environment often calls for conservation measures, conservation goals will not be met without their support. This implies more than a purely sectorial approach to the problem and in the case of the Air project, has led to the execution of a large number of rural development activities, ranging from well digging and health training to adult literacy and woodless, adobe construction (Newby, 1989).

The reserve not only provides a physical, administrative and legislative framework for natural resource management, but is also a focal point, locally and nationally, for pride and involvement. The reserve and the IUCN/WWF project that supports it are perceived as an innovative attempt to reconcile conservation with development through a broad-based programme geared to the protection, restoration and sustainable use of the area's natural resources. Because of its breathtaking desert scenery, its cultural and prehistoric sites, and its unique wildlife, the reserve is becoming a popular tourist venue. Unlike agriculture or stock rearing, tourism and the economy derived from it are sheltered from the vagaries and perturbations of the climate. An information centre has been built, incorporating educational displays, a locale for hiring guides for trekking, and a crafts shop.

\section{Site-specific rules and regulations}

Establishment of the reserve has enabled legislation to be tailored specifically to the area's needs and potential. Unlike national law regulating natural resource use and abuse, which tends to be too general, out of date, or inappropriate for real management purposes, the reserve's regulations are site-specific and as a result entirely relevant.

Although some authors (e.g. Bourgeot, 1988) have argued that the establishment of the reserve has had a detrimental effect by depriving people of access to resources or land previously available, there is little evidence of this. In fact, many people living outside the reserve have asked that its boundaries be extended to encompass their own land. Without the reserve's regulations and, more important, management capacity, adjacent land is being plundered to satisfy the everincreasing fuel-wood needs of nearby towns.

To a large extent the legislation covering the reserve reiterates, albeit in a site-specific way, national law and has brought with it no fundamental changes and restrictions to the people's way of life. Although access is prohibited to some 12 per cent of the reserve's desert centre (a wildlife sanctuary), this land was very rarely used by the local population.

The same is true of bush meat and a ban on hunting. People used to hunt for food and for meat for the caravan trade (Lhote, 1951), but this is rarely done today: wildlife is too rare and inaccessible to render it profitable. In fact the general attitude to wildlife is one of benevolence, the Twareg often stressing its cultural and aesthetic values. As might be expected of a people almost wholly reliant on natural resources for its existence, perception of environmental health is acute and wildlife is seen as both an indicator and a product of environmental well-being. If wildlife populations are under threat today, it is not from the Twareg but from drought, desertification, harassment from tourists hunting by the armed forces.

National restrictions on the use of certain tree species have been enforced, affecting to a certain extent the livelihoods of artisans who produce household objects such as mortars, spoons, saddles, etc. Compensatory action is being taken through the import of mortars and it is hoped to establish a commercial network with the artisans affected. Whatever the resource, the ultimate aim is to permit use within sustainable limits. In the absence of 


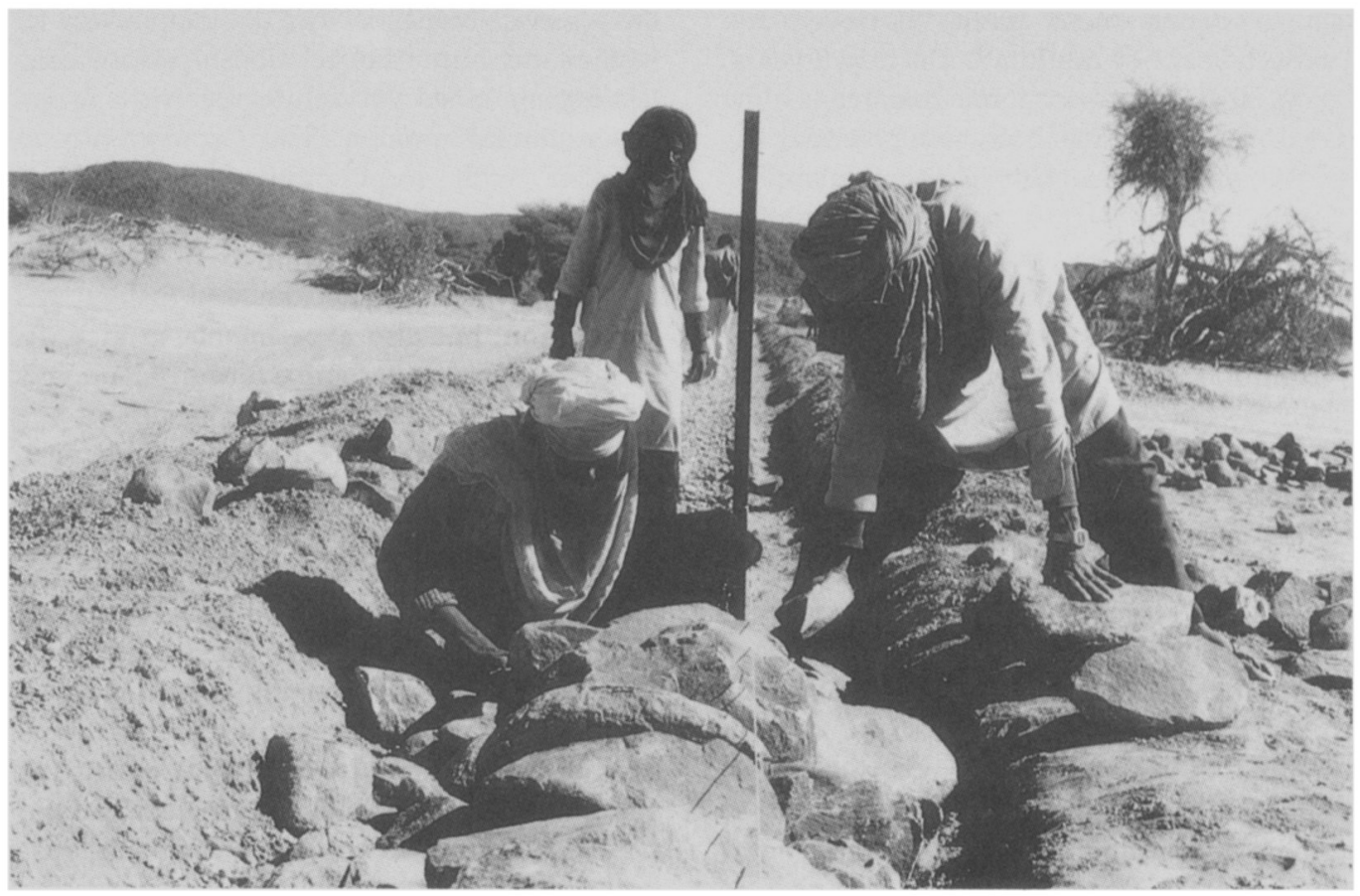

Appropriate technology and local materials allow local people to manage their environment in a sustainable way. Here a low, drystone dyke is helping reclaim degraded land (Meg Gawler/WWF).

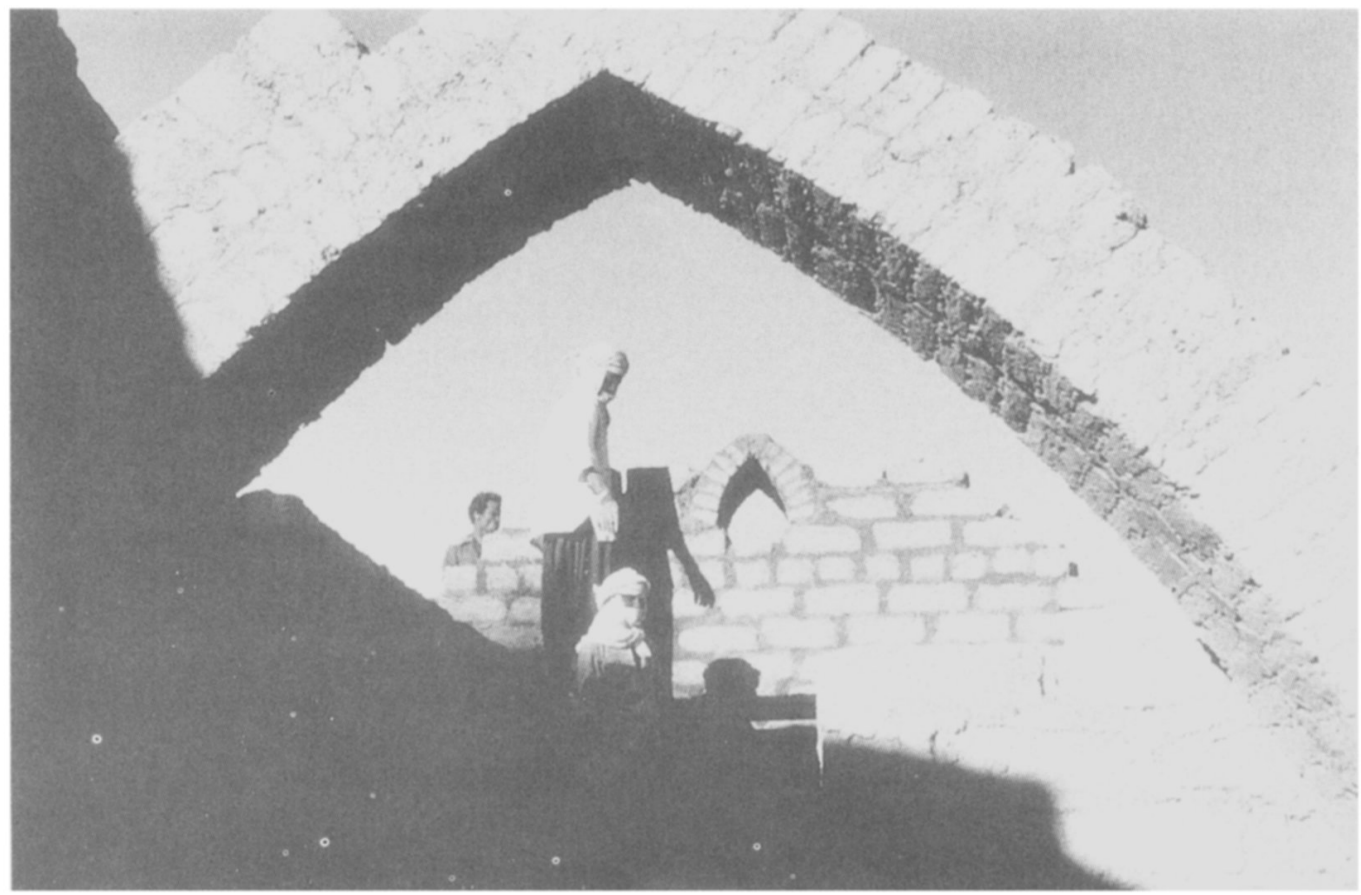

Newly introduced adobe construction techniques are solving housing problems without increased destruction of trees and thatch for roofing materials (John Newby/WWF). 
data to define these limits, however, the approach is one of caution. In the next 3 years, ecological and socio-economic research is to be undertaken to define both the potential for and the constraints on natural resource use.

Predator control is a bone of contention between the reserve's authorities and the local population. Although the law specifically forbids it, the use of poisons such as strychnine to control jackals Canis aureus and hyaenas Hyaena hyaena is generally condoned by local administrators. The reserve's management recognizes that livestock predation is a problem but it can hardly be expected to accept the use of such environmentally dangerous poisons. Use of strychnine has killed non-target species like crows, ravens and vultures and beneficial carnivores like the fennec Fennecus zerda and Ruppell's fox Vulpes ruppelli. Attempts to solve this thorny issue might entail granting people living in high-risk areas periodic dispensation to use traditional methods of control. Experiments will also be carried out using non-lethal traps.

Although it is impossible to please all of the people all of the time, the positive aspects of the reserve's creation by far outweigh the disadvantages. Thanks partially to a series of relatively good rainy seasons (1987-89), results to date have been encouraging and in spite of the fact that habitat rehabilitation takes a long time, improvements are already discernible. These have been noticed by the local population and have heightened their appreciation of the reserve's value. Forest resources, after years of drought and overuse, are recuperating and wildlife is more abundant.

\section{Local participation and responsibility}

Ultimately, the aim is to transfer as much responsibility as possible for the reserve's management, law enforcement and surveillance from the largely 'alien' government staff to the land users themselves (DFPP, 1990). To facilitate this a network of voluntary Representatives, composed of locally respected farmers and herders, has been set up. The Representatives form the vital link between the reserve's managers and the people, and to further this important relationship close contact is maintained through regular visits and a lively annual reunion. The Representatives, together with locally recruited extension agents, are essential for developing the understanding and consent required to undertake not only wildlife protection and habitat rehabilitation, but also experiments to identify and demonstrate alternative forms of land and natural resource use.

Politics and practice apart, the development of a truly popular and participatory approach is by no means easy considering the immensity of the reserve and the highly uneven distribution of its population. The issue is further compounded by the prickly question of common resource management, where land use may at best be only temporary. Until real ownership of resources such as wildlife, pasture or water can be established, making local people responsible for them is unlikely. Traditional ownership or rights to land and resources have been totally deformed by the political, social and climatic changes of the past century, and it is only now that Niger is tackling the problem through the development of a Rural Code for agrarian reform.

The project's rural development and land rehabilitation activities do benefit from a high degree of local participation, but this has invariably been developed on an employeremployee basis. On the whole it has been difficult to mobilize true participation and there are several reasons for this: lack of conviction, fatalism, precedents set by other projects, politics, etc. Project 'philosophy' is based on the premise that popular support and voluntary participation can come about only through greater responsibility and conviction in what one is doing. Its approach is to try and produce tangible evidence for the application of specific activities or measures and as a result, emphasis is put on experimentation, with the risks and costs being borne mainly by the project. Clearly, unless the people perceive real benefits for the use of their time and energy, they will not voluntarily undertake new or extra activities. Having said this, the project has nonetheless made considerable progress 
in several fields, including wells, woodless construction, garden protection and solar drying of vegetables. In all these cases emphasis has been placed firmly on the dual aspects of demonstration and training.

\section{Discussion and conclusions}

Given that conservation of natural resources and modification of traditional land-use practices are both long-term undertakings, the results so far are encouraging. The Air Mountains experience has confirmed the role that appropriately designed and run protected areas can play in natural resource management and by extension, sustainable rural development. What guarantees are there, however, that the short-term gains and benefits made possible by the reserve's presence can be sustained, or that the resources eventually restored will be used correctly? In theory, the solution lies in effective management. In reality, management is unlikely to work unless it is realistic enough to gain popular support.

As we near the end of the twentieth century, the Twareg of the Air can look back on a time of enormous change. For many, though, life goes on much as before, tied inextricably to nature and the natural world, to the coming and going of the seasons, to the good years and to the bad. Existence in the Air is harsh, but by and large its nature remains bountiful. There are gazelles, Barbary sheep and ostriches, deep waterholes in the mountains and well-wooded valleys. Protected areas can help maintain and improve this desirable situation.

In other parts of the Sahel, however, the land can no longer sustain the people's modest needs: pastures are overgrazed, soils are eroded, wildlife has disappeared. More and more people are obliged to compete for diminishing returns and be it his fault or not, the fact remains the same: man no longer lives in harmony with the resources he requires for his subsistence. Seemingly bereft of viable alternatives, he is obliged to go deeper and deeper into environmental debt until the inevitable happens and the land is destroyed or can no longer support even sub-subsistence require- ments. It is difficult to see how the Sahel and its natural resources can be restored, nurtured and coaxed back into providing sustenance to growing populations. Here again, protected areas offer considerable potential for innovative management and habitat rehabilitation.

In a rapidly changing world, protected areas must also change to meet the demands of new situations. It is no longer reasonable to 'set aside' large tracts of Africa for the unique benefit of wildlife or privileged visitors. It is equally as unwise to throw the baby out with the bathwater and reject the whole concept of protected areas because some parks and reserves are no longer appropriate. On the contrary, the protected areas approach to sustainable development, through the conservation and management of land and natural resources, is more urgently needed than ever before.

\section{Acknowledgments}

Warmest thanks to Susan Canney for the coffee, comments and criticism generously given during the writing of this paper.

\section{References}

Barth, H. 1857-8. Travels and Discoveries in North and Central Africa. Longmans, London.

Bernus, E. and Bernus, S. 1973. Du sel et des dattes. Etudes Nigerriennes No. 31, CNRSH, Niamey.

Bourgeot, A. 1988. Rapport de mission 'Pasoraliste'. Unpubl. report to Projet UICN/WWF Airr/Ténéré.

Buchanan, A. 1921. Out of the World North of Nigeria. Murray, London.

Chopard, L. and Villiers, A. (Eds.) 1950. Contribution a l'etude de l'Aïr. Mem. Ifan, No. 10. Larose, Paris.

DFPP. 1990. Conservation et Gestion des Ressources Naturelles dans l'Air et le Ténéré (Niger): Proposition pour la Deuxieme Phase du Projet. DFPP, Niamey.

Dulieu, D. 1981. The vegetation of the Takolokouzet Massif and surrounding area in the Eastern Aïr Mountains, Republic of Niger. Unpubl. report to IUCN/WWF.

Durand, A., Lang, J., Morel, A. and Roset, J-P. 1983. Evolution geomorphologique, stratigraphique et paleolithique au Pleistocene superieur et a l'Holocene de l'Aïr Oriental (Sahara meridional, Niger). Revue de Geologie Dynamique et de Geographie Physique, 24, 47-59. 
Fairon, J. 1975. Contribution a l'ornithologie de l'Aïr (Niger). Le Gerfault, 65, 107-134.

Foureau, F. 1902. D'Alger au Congo par le Tchad. Mission Saharienne Foureau-Lamy. Masson, Paris.

Fugelstad, F. 1983. A History of Niger. African Studies Series No. 41, Cambridge University Press, Cambridge.

Grettenberger, J.F. 1987. Ecology of the Dorcas gazelle in northern Niger. Mammalia, 51, 527-536.

Grettenberger, J.F. and Newby, J.E. 1986. The status and ecology of the Dama gazelle in the Aïr and Ténéré National Nature Reserve, Niger. Biol. Conserv. 38, 207-216.

Grettenberger, J.F. and Newby, J.E. 1990a. Une classification de paysages pour la Reserve Naturelle Nationale de l'Air et du Ténéré. Serie des Rapports Techniques No. 2,UICN/WWF, Niamey, Niger.

Grettenberger, J.F. and Newby, J.E. 1990b. Plan d'amenagement pour la Reserve Naturelle Nationale de l'Aïr et du Ténéré: Concepts et cadre general. Serie des Rapports Techniques No. 1, UICN/WWF, Niamey, Niger.

Grettenberger, J.F., Newby, J, and Monson, K. 1984. La Reserve Naturelle Nationale de l'Aïr et du Ténéré: Proposition pour un plan directeur d'amenagement pour la conservation et l'utilisation des ressources naturelles. UICN/WWF, Niamey (unpublished report).

Hagener, L. 1990. Gestion des paturages dans la Reserve Naturelle Nationale de l'Aïr et du Ténéré. Serie des Rapports Techniques No. 10, UICN/WWF, Niamey, Niger.

Hammer, D. 1990. Traditional gardening systems in the Aïr Mountains of Niger. Serie des Rapports Techniques, 13, UICN/WWF, Niger.

Ingram, G.B. 1990. Multi-gene pool surveys in areas with rapid genetic erosion: An example from the Aïr Mountains, northern Niger. Conservation Biology, 4, 78-90.

Lhote, H. 1951. La Chasse Chez les Touaregs. AmiotDumont, Paris.

Lhote, H. 1961. L'epopee du Ténéré. Gallimard. Paris. Lhote, H. 1976. Vers d'autres Tassilis. Arthaud, Paris.

Magin, C.D. 1991a. Status of wildlife populations in the Aïr and Ténéré National Nature Reserve 1988-89. Serie des Rapports Techniques No. 14, IUCN/WWF, Niamey, Niger.

Magin, C.D. 1991b. Variations saisonieres dans le choix de l'habitat des animaux domestiques et de la faune sauvage de la Reserve Naturelle Nationale de l'Aïr et du Ténéré. Serie des Rapports Techniques No. 15, UICN/WWF, Niamey, Niger.

Magin, C.D. 1991c. La biologie reproductrice de l'autruche (Struthio camelus) dans la Réserve Naturelle Nationale de l'Aïr et du Ténéré. Serie des Rapports Techniques No. 16, UICN/WWF, Niamey, Niger.
Magin, C.D. 1991d. L'ecologie de l'aoudad ou mouflon a manchettes (Ammotragus lervia) dans la Reserve Naturelle Nationale. Serie des Rapports Techniques No. 17, UICN/WWF, Niamey, Niger.

de Mire, B and Gillet, H. 1956. Contribution a l'etude de la flore du Massif de l'Aür (Sahara Meridional). Journal d'Agric. Tropicale et de Botanique Appliquee. Part 1: T.III, 5-6 (mai-juin 1956), pp. 221-247; Part 2: T.III, 7-8 (juil.-aout 1956), pp. 422-438; Part 3: T.III, 11 (nov. 1956), pp. 701-760; Part 4: T.III, 12 (dec. 1956), pp. 857-886.

Monson, K. 1985. The plants of the Air and Ténéré National Nature Reserve. Unpubl. report to the Nigerien Forest Service.

Morel, A. 1985. Les hauts massifs de l'Aïr (Niger) et leurs piemonts. Université de Grenoble.

Newby, J.E. 1982. Avant-projet de classement d'une aire protegee dans l'Airr et le Ténéré (Republique due Niger). IUCN/WWF, Gland.

Newby, J.E. 1986. The fabulous lake of wild sorghum. WWF News, 40.

Newby, J.E. 1989. The Aïr and Ténéré National Nature Reserve. Paper presented to Workshop on Wildlife Resource Management, Zimbabwe, 19-24 September 1989.

Newby, J.E. 1990. Le regime pluviometrique de la Reserve Naturelle Nationale de l'Aïr et du Ténéré et de ses environs. UICN/WWF, Niamey, Niger.

Newby, J.E. and Grettenberger, J.F. 1986. The human dimension in natural resource conservation: A Sahelian example from Niger. Environmental Conservation, 13, 249-256.

Newby, J.E., Grettenberger, J.F. and Watkins, J. 1987. The birds of the Northern Aïr, Niger. Malimbus, 9, 4-17.

Newby, J.E.and Jones, D.M. 1980. Ecological studies in Niger: Takolokouzet (Air Massif). Report to the Government of Niger. ZSL/WWF/IUCN.

Peyre de Fabregues, B. and Lebrun, J.-P. 1976. Catalogue des Plantes Vasculaires $d u$ Niger. I.E.M.V.T, Paris.

Rodd, R. 1926. People of the Veil. Macmillan, London.

Roset, J-.P. 1989. Neolithisation, neolithique et postneolithique au Niger nord-oriental. Bulletin de l'Association Francaise pour l'Etude du Quartenaire, 32, $203-214$.

Salifou, A. 1973. Kaoussan ou la revolte senoussiste. Etudes Nigeriennes No. 33, CNRSH, Niamey.

Watkins, J.H. 1986. Observations on ostrich in Northern Niger. Unpubl. report to the Nigerien Forest Service.

Watkins, L.M. 1986. Aoudad (Ammotragus lervia) of the Air Mountains, Niger. Unpubl. report to the Nigerien Forest Service.

Newby, J.E., WWF International, Avenue du Mont Blanc, CH-1196, Gland, Switzerland. 